\title{
PENGARUH PENDIDIKAN DAN PELATIHAN (DIKLAT) TERHADAP PRESTASI KERJA PEGAWAI DI RUMAH SAKIT UMUM DAERAH AEK KANOPAN KABUPATEN LABUHANBATU UTARA
}

\author{
Desmawaty Hasibuan \\ Fakultas Ekonomi dan Bisnis, Prodi Manajemen, Universitas Labuhanbatu \\ Email : hasibuandesmawaty@gmail.com
}

\begin{abstract}
Abstrak
Penelitian ini bertujuan untuk menganalisis pengaruh Pendidikan dan Pelatihan Terhadap Prestasi Kerja Pegawai di Rumah Sakit Umum Daerah Aek Kanopan Kabupaten Labuhanbatu Utara. Populasi dalam penelitian ini 82 responden, Hasil penelitian menunjukkan bahwa pendidikan dan pelatihan berpegaruh secara simultan Terhadap prestasi kerja pegawai. Hal tersebut dapat diketahui dari hasil uji simultan yang memiliki nilai $F_{\text {hitung }}$ sebesar 31,332 dan nilai $F_{\text {tabel }}$ sebesar 3,11 ( $\left.t_{\text {hitung }}>t_{\text {tabel }}: 31,332>3,11\right)$ serta taraf signifikasi $0,00<0.05$, dengan demikian dapat disimpulkan bahwa $\mathrm{H}_{\mathrm{a}}$ diterima dan $\mathrm{H}_{0}$ ditolak, yang berarti terdapat pengaruh yang positif dan signifikan antara pendidikan dan pelatihan secara simultan terhadap prestasi kerja pegawai di Rumah Sakit Umum Daerah Aek Kanopan Kabupaten Labuhanbatu Utara. Nilai koefisien determinasi sebesar 0,627 menunjukkan bahwa kedua variabel independen (pendidikan dan pelatihan) mempunyai pengaruh sebesar $62,7 \%$ terhadap variabel terikat (prestasi kerja), sedangkan sisanya sebesar 37,3\% dipengaruji oleh variabel lain yang tidak diteliti dalam penelitian ini. Hal ini menunjukkan hubungan antara pendidikan dan pelatihan terhadap prestasi kerja pegawai pada di Rumah Sakit UmumDaerah Aek Kanopan Kabupaten Labuhanbatu Utara sebesar 62,7 \% yang tergolong sangat kuat.
\end{abstract}

\section{Kata Kunci :Pendidikan, Pelatihan dan Prestasi Kerja.}

\section{I . PENDAHULUAN}

Peranan manusia sebagai sumber daya dalam organisasi semakin diyakini kepentingannya. Sebagai lembaga atau organisasi, setiap organisasi harus terus menerus bertumbuh baik secara kuantitatif maupun kualitatif. Kemampuan bertumbuh ini memungkinkannya tangguh bukan saja dalam mempertahankan eksistensinya akan tetapi juga dalam mengembangkan dirinya secara mantap dalam rangka pencapaian tujuan. Manusia memang merupakan salah satu unsur manajemen dalam proses pencapaian tujuan, namun unsur manusia memiliki posisi yang lebih strategis dibanding unsur-unsur lainnya. Karena keberadaan unsur lain sangat ditentukan dari keandalan sumberdaya manusia.
Namun manusia di zaman modern ini masih membutuhkan suatu program pendidikan serta pelatihan yang bertujuan untuk memperbaiki penguasaan berbagai keterampilan dan teknik pelaksanaan kerja tertentu untuk kebutuhan sekarang.

Tujuan pengembangan pegawai dalam hal ini pendidikan dan pelatihan adalah untuk memperbaiki efektivitas kerja pegawai dalam mencapai hasil kerja yang telah ditetapkan. Perbaikan efektivitas kerja dapat dilakukan dengan cara memperbaiki atau meningkatkan pengetahuan pegawai, keterampilan pegawai, maupun sikap pegawai Rumah Sakit Umum Daerah aek Kanopan Kabupaten Labuhanbatu Utara itu sendiri terhadap tugas-tugasnya.Salah satu faktor 
yang dianggap penting bagi peningkatan prestasi kerja pegawai yaitu Adanya pendidikan dan pelatihan bagi pegawai atau karyawan. Karyawan diharapkan menyukai tantangan dan mampu memecahkan permasalahan dalam pekerjaannya dengan lebih baik yang pada akhirnya dapat mendukung tercapainya prestasi kerja secara memuaskan perlu didukung adanya pendidikan dan pelatihan terlebih dahulu. Pemimpin dalam hal ini perlu memberi kesempatan kepada bawahan agar mereka dapat mengaktualisasikan diri secara baik dan wajar.

Dengan adanya pendidikan dan
pelatihan tersebut maka akan
menghasilkan sumber daya manusia yang
berkualitas dan mampu memberikan
konstribusi yang terbaik dalam pencapaian
tujuan. Pendidikan dan pelatihan ini
diberikan kepada para pegawai, juga
sering mendorong para pegawai untuk
bekerja lebih keras. Hal ini disebabkan
karena pegawai-pegawai di Rumah Sakit
Umum Daerah Aek Kanopan Kabupaten
Labuhanbatu Utara yang telah mengetahui
tugas-tugas dan tanggung jawabnya akan
berusaha mencapai tingkat moral kerja
yang tinggi, kesadaran akan pentingnya
pendidikan dan pelatihan bagi Pegawai
Rumah Sakit Umum Daerah Aek kanopan
Kabupaten Labuhanbatu Utara untuk dapat
mengikuti adanya perubahan-perubahan
teknologi yang akan dipakai di
intansi/perusahaan. Dengan demikian
usaha peningkatan pegawai agar
berkualitas baik mental maupun
kemampuan tidak boleh diabaikan.
Pendidikan dan pelatihan digalakkan
bukan hanya kepada pegawai-pegawai
baru tetapi juga pada pegawai yang lama
karena adanya tuntutan dari tugas-tugas
yang sekarang ataupun untuk kenaikan
pangkat. Para pegawai.

Jadi dengan adanya pendidikan pelatihan diharapkan akan menunjang keberadaan suatu organisasi agar mampu bersaing dimasa sekarang maupun dimasa yang akan datang, serta mampu menunjang keberadaan organisasi dalam mencapai tujuan yang telah ditentukan.

Berdasarkan observasi pada pra penelitian yang telah dilaksanakan pada Rumah Sakit Umum Daerah Aek Kanopan Kabupaten Labuhanbatu Utara dengan melihat aktivitas pegawai sebagai tolak ukur menunjukkan bahwa prestasi kerja pegawai belum maksimal, masih adanya beberapa pegawai yang belum memahami tugas dan tanggung jawab yang diberikan Sehingga hal tersebut akan berdampak terhadap tanggung jawab pegawai dalam menyelesaikan pekerjaannya.

Berdasarkan dari latar belakang masalah yang terjadi pada pegawai di RSUD Kabupaten Labuhanbatu Utara maka penulis tertarik untuk melakukan penelitian dengan judul "Pengaruh Pendidikan dan Pelatihan (Diklat) Terhadap Prestasi Kerja Pegawai di Rumah Sakit Umum Daerah Aek Kanopan Kabupaten Labuhanbatu Utara".

\section{Perumusan Masalah}

Sedangkan yang menjadi rumusan masalah dalam penelitian ini adalah :

1. Apakah Pendidikan Secara Parsial Berpengaruh Positif dan Signifikan Terhadap Prestasi Kerja Pegawai di Rumah Sakit Umum Daerah Aek Kanopan Kabupaten Labuhanbatu Utara.

2. Apakah Pelatihan Secara Parsial Berpengaruh Positif dan Sugnifikan Terhadap Prestasi Kerja Pegawai di Rumah Sakit Umum Daerah Aek Kanopan Kabupaten Labuhanbatu Utara. 
3. Apakah Pendidikan dan Pelatihan (Diklat) Secara Simultan Berpengaruh Positif Dan Signifikan Terhadap Prestasi Kerja Pegawai di Rumah Sakit Umum Daerah Aek Kanopan Kabupaten Labuhanbatu Utara.

\section{Tujuan Penelitian}

Tujuan yang ingin dicapai dalam penelitian ini adalah :

1. Untuk Mengetahui Pengaruh Pendidikan Terhadap Prestasi Kerja Pegawai di Rumah Sakit Umum Daerah Aek Kanopan Kabupaten Labuhanbatu Utara.

2. Untuk Mengetahui Pengaruh Pelatihan Terhadap Prestasi Kerja Pegawai di Rumah Sakit Umum Daerah Aek Kanopan Kabupaten Labuhanbatu Utara.

3. Untuk Mengetahui Pengaruh Pendidikan dan Pelathan (Diklat) Secara Simultan Terhadap Prestasi Kerja Pegawai di Rumah Sakit Umum Daerah Aek Kanopan Kabupaten Labuhanbatu Utara.

\section{LANDASAN TEORI}

\section{Pendidikan}

Pendidikan adalah suatu kegiatan yang terencana dengan persyaratan tertentu seperti : dilakukan dengan sadar,bertujuan, terorganisir secara sitematis dan hasilnya dapat diukur. Dengan demikian melalui pendidikan menciptakan manusia manusia yang berkwalitas. Sebagaimana termaktub dalam UU Nomor 2 tahun 1989 tentang Sistem Pendidikan Nasional, mengatakan : Pendidikan Nasional befungsi untuk mengembangkan kemampuan serta meningkatkan mutu kehidupan dan martabat manusia Indonesia serta bertujuan untuk mencerdaskan kehidupan bangsa dan mengembangkan manusia seutuhnya, yaitu manusia yang mberiman, bertaqwa terhadap Tuhan Yang Maha Esa dan berbudi pekerti luhur, memiliki pengetahuan dan keterampilan, kesehatan jasmani dan rohani, kepribadian yang mantap dan mandiri serta tanggungjawab terhadap masyarakat dan bangsa.

Menurut Soekidjo Notoatmodjo (2003 :16) Pendidikan adalah segala upaya yang direncanakan untuk mempengaruhi orang lain baik individu, kelompok, atau masyarakat sehingga mereka melakukan apa yang diharapkan oleh pelaku pendidikan.

Berdasarkan defenisi yang telah dipaparkan, maka dapat disimpulkan bahwa pendidikan dan pelatihan merupakan serangkaian kegiatan yang mengutamakan pengetahuan, keterampilan dan peningkatan sikap seseorang dalam melaksanakan tugasnya dalam rangka pencapaian tujuan organisasi yang efektif dan efisien.

\section{Pelatihan}

Pelatihan adalah suatu proses mengajarkan keahlian dan memberikan pengetahuan yang perlu,serta sikap supaya mereka dapat melaksanakan tanggungjawab sesuai dengan standard, berbeda dengan pendidikan yang memeberikan pengetahuan dengan subyek tertentu secara umum; karena pelatihan memusatkan diri pada kebutuhan secara khusus dalam pekerjaan dengan tujuan memperbaiki kinerja pegawai

Mangkunegara, 2000).

Menurut Veithzal Rivai (2004:226), Pelatihan adalah proses sistematis mengubah tingkah laku pegawai untuk mencapai tujuan organisasi. Sedangkan menurut Moekijat menjelaskan istilah latihan untuk menunjukkan setiap 
proses untuk menunjukkan bakat, keterampilan dan kemampuan guna menyelesaikan pekerjaan-pekerjaan tertentu.

Dari uraian diatas dapat disimpulkan bahwa tujuan pelatihan adalah untuk memperbaiki penguasaan berbagai keterampilan dan tehnik pelaksanaan kerja tertentu; terinci dan riutin, khusunya yang dibutuhkan sekrang, sehingga terjaminnya tenaga tenaga atau sumber daya manusia yang handal pada perusahaan.

\section{Prestasi Kerja}

Prestasi kerja adalah salah satu tujuan pengelolaan tenaga kerja dalam meningkatkan prestasi kerja pada suatu organisasi. Faktor prestasi kerja tersebut merupakan hal yang akan menentukan kelangsungan hidup suatu organisasi atau perusahaan.

Menurut Malayu S.P.Hasibuan (2008:94), Prestasi kerja adalah suatu hasil kerja yang dicapai seseorang dalam melaksanakan tugas-tugas yang dibebankan kepadanya yang didasarkan atas kecakapan, pengalaman dan kesungguhan serta waktu. Sedangkan menurut T. Hani Handoko (2007: 135), Prestasi kerja adalah suatu hasil kerja yang dicapai organisasi mengevaluasi atau menilai karyawannya.

Dari beberapa pengertian prestasi kerja di atas maka dapat disimpulkan bahwa prestasi kerja adalah hasil kerja seseorang berdasarkan beban tanggung jawab yang diberikan kepadanya.

\section{METODE PENELITIAN}

\section{Populasi dan Sampel}

Menururt Sugiono (2009) "populasi adalah wilayah generalisasi yang terdiri atas objek/subjek yang mempunyai kualitas dan karakteristik tertentu yang ditetapkan oleh peneliti untuk dipelajari dan ditarik kesimpulannya". Populasi dari penelitian ini adalah seluruh pegawai di Rumah Sakit Umum Daerah Aek Kanopan Kabupaten Labuhanbatu Utara yang berjumlah 104 orang. Untuk menentukan sampel yang tepat dan sesuai dengan ketentuan yang berlaku dalam penelitian. Penulis dalam menentukan jumlah sampel menggunakan rumus Slovin. berikut disajikan rumus dan hasil perhitungan yang dilakukan :

Dimana :

$\mathrm{N}=$ Jumlah Populasi.

$\mathrm{n}=$ Jumlah sampel.

$\mathrm{e}=$ Tingkat kesalahan dalam memilih anggota sampel yang ditolelir sebesar $5 \%$.

Menggunakan rumus Slovin, maka ukuran sampel dapat dihitung sebagai berikut :

\section{Menurut Slovin}

$$
\begin{aligned}
& \mathrm{n}=\frac{N}{1+n\left(e^{2}\right)} \\
& \mathrm{n}=\frac{104}{1+104\left(0,05^{2}\right)} \\
& \mathrm{n}=82
\end{aligned}
$$

\section{METODE ANALISIS DATA}

\section{Analisis Regresi Linier Berganda}

Analisis regrasi linier berganda bertujuan untuk mengetahui hubungan linier antara beberapa variabel bebas dengan variabel terikat. Analisis linier 
beganda dapat dirumuskan sebagai berikut

$$
\mathrm{Y}=\mathrm{a}+\mathrm{b}_{1} \mathrm{X}_{1}+\mathrm{b}_{2} \mathrm{X}_{2}+\mathrm{e}
$$

Keterangan :

$\mathrm{Y} \quad=$ Variabel prestasi kerja pegawai

$\mathrm{X}_{1} \quad=\quad$ Variabel

pendidikan

$\mathrm{X}_{2} \quad=\quad$ Variabel pelatihan

$\mathrm{a} \quad=$ Konstanta
$\mathrm{b}_{1}, \mathrm{~b}_{2}=$ Koefisien regresi
variabel independen

e $\quad=$ Standart error

\section{Uji Hipotesis}

Pengujian hipotesis dilakukan dengan signifikan secara parsial (uji-t) signifikan secara simultan (uji-f) dan pengujian koefisien determinasi $\left(\mathrm{R}^{2}\right)$ yaitu sebagai berikut :

\section{Uji Signifikan secara parsial (uji-t)}

Uji $t$ digunakan untuk mengetahui pengaruh variabel independen secara parsial terhadap variabel dependen.

\section{Uji Signifikan Simultan (Uji F)}

Uji F digunakan untuk mengetahui pengaruh seluruh variabel independen yakni pendidikan $\left(\mathrm{X}_{1}\right)$ dan pelatihan $\left(\mathrm{X}_{2}\right)$ terhadap variabel dependen yakni prestasi kerja pegawai (Y).

\section{Koefisien Determinasi $\left(\mathbf{R}^{2}\right)$}

Koefisien determinasi dimaksudkan untuk mengetahui seberapa jauh kemampuan model dalam menerangkan variasi variabel dependen. Nilai koefisien determinasi antar nol dan satu. Nilai yang mendekati satu berarti variabel-variabel independen memberikan hampir semua informasi yang dibutuhkan untuk memprediksi variasi variabel dependen.

\section{HASIL PENELITIAN}

\section{Hasil Analisis Regresi Linier Berganda}

Analisis regresi linier berganda bertujuan untuk mengetahui pengaruh dari variabel-variabel independen terhadap variabel dependen, dapat dilihat pada tabel berikut ini :

\section{Tabel 4.11}

Hasil Analisis Regresi Linier Berganda

\begin{tabular}{|c|c|c|c|c|c|c|}
\hline \multicolumn{7}{|c|}{ Coefficients $^{\mathrm{a}}$} \\
\hline \multirow{2}{*}{\multicolumn{2}{|c|}{ Model }} & \multicolumn{2}{|c|}{$\begin{array}{l}\text { Unstandardized } \\
\text { Coefficients }\end{array}$} & \multirow{2}{*}{$\begin{array}{c}\begin{array}{c}\text { Standardize } \\
\mathrm{d} \\
\text { Coefficients }\end{array} \\
\text { Beta }\end{array}$} & \multirow[t]{2}{*}{$\mathrm{T}$} & \multirow{2}{*}{$\begin{array}{l}\text { Si } \\
\text { g. }\end{array}$} \\
\hline & & B & $\begin{array}{l}\text { Std. } \\
\text { Error }\end{array}$ & & & \\
\hline 1 & $\begin{array}{l}\text { (Consta } \\
\text { nt) }\end{array}$ & $\begin{array}{r}1,52 \\
7\end{array}$ & 1,868 & & $\begin{array}{r}69 \\
9\end{array}$ & $\begin{array}{l}, 0 \\
00\end{array}$ \\
\hline & $\begin{array}{l}\text { Pendidi } \\
\text { kan }\end{array}$ & ,391 & ,081 & 591 & $\begin{array}{r}6,5 \\
95\end{array}$ & $\begin{array}{l}0 \\
00\end{array}$ \\
\hline & $\begin{array}{l}\text { Pelatiha } \\
\mathrm{n}\end{array}$ & ,482 & ,088 & 621 & $\begin{array}{r}6,9 \\
77\end{array}$ & $\begin{array}{l}0 \\
00\end{array}$ \\
\hline
\end{tabular}

Dari tabel diatas dapat diketahui model persamaan regresi sebagai berikut :

$$
Y=1,527+0.391 X_{1}+0,482 X_{2}
$$

Persamaan regresi linier berganda tersebut dapat diuraikan sebagai berikut :

1. Nilai konstanta (a) sebesar 1,527 . Nilai ini memiliki arti bahwa jika variabel pendidikan dan peran insentif bernilai 0 , maka produktivitas kerja bernilai 1,527.

2. Nilai koefisien $X_{1}\left(b_{1}\right)$ sebesar 0,391 . Nilai ini memiliki arti bahwa jika pendidikan $\left(\mathrm{X}_{1}\right)$ mengalami kenaikan sebesar satu satuan, maka produktivitas kerja (Y) mengalami peningkatan sebesar 0,391. Koefisien bernilai 
positif artinya antara $\mathrm{X}_{1}$ dengan $\mathrm{Y}$ memiliki hubungan positif.

3. Nilai koefisien $X_{2} \quad\left(b_{2}\right)$ sebesar 0,482 . Nilai ini memiliki arti bahwa jika peran insentif $\left(\mathrm{X}_{2}\right)$ mengalami kenaikan sebesar satu satuan, maka produktrivitas kerja (Y) mengalami peningkatan sebesar 0,482. Koefisien bernilai positif artinya antara $\mathrm{X}_{2}$ dengan $\mathrm{Y}$ memiliki hubungan positif.

\section{Uji Parsial (Uji-t)}

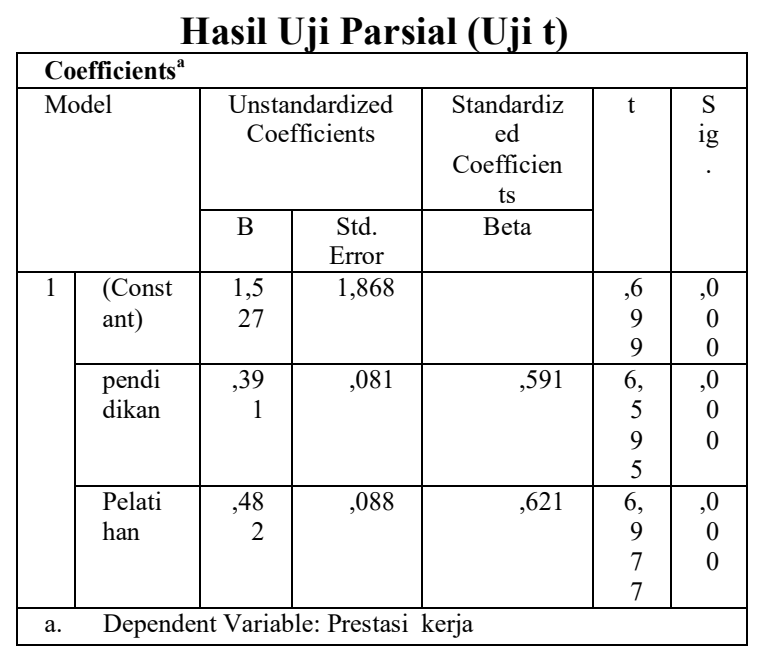

\section{Uji Simultan (Uji-F)}

Hasil Uji Simultan (Uji F)

\begin{tabular}{|c|c|c|c|c|c|c|}
\hline \multicolumn{7}{|c|}{ ANOVA $^{\mathrm{a}}$} \\
\hline \multicolumn{2}{|c|}{ Model } & Sum & $\mathrm{D}$ & Mea & $\mathrm{F}$ & $\mathrm{Si}$ \\
\hline \multirow[t]{3}{*}{1} & $\begin{array}{l}\text { Regre } \\
\text { ssion }\end{array}$ & 63,454 & 2 & $\begin{array}{r}31,1 \\
26\end{array}$ & $\begin{array}{r}31 \\
3 \\
32\end{array}$ & $\begin{array}{r}, 0 \\
00 \\
\text { b }\end{array}$ \\
\hline & $\begin{array}{l}\text { Resid } \\
\text { ual }\end{array}$ & 26,122 & $\begin{array}{l}7 \\
9\end{array}$ & 897 & & \\
\hline & Total & 89,898 & $\begin{array}{l}8 \\
1\end{array}$ & & & \\
\hline & nde & riable: & & rja & & \\
\hline
\end{tabular}

\section{PEMBAHASAN}

\section{a. Pengaruh pendidikan $\left(X_{1}\right)$ Terhadap prestasi kerja pegawai (Y)}

Bedasarkan hasil penelitian secara parsial (Uji-t) Terdapat pengaruh yang positif dan signifikan antara pendidikan terhadap prestasi kerja di Rumah Sakit Umum Daerah Aek Kanopan Kabupaten Labuhanbatu Utara.. Berdasarkan hipotesis pertama ini dilakukan pengujian dengan menggunakan uji t. Hasil perhitungan secara parsial ini menunjukkan bahwa pendidikan memiliki nilai $t_{\text {hitung }}$ sebesar 6,595 dan nilai $t_{\text {tabel }}$ sebesar $1,668\left(t_{\text {hitung }}>t_{\text {tabel }}: 6,595>1,668\right)$ serta taraf signifikasi $0,00<0.05$, dengan demikian dapat disimpulkan bahwa $\mathrm{H}_{\mathrm{a}}$ diterima dan $\mathrm{H}_{0}$ ditolak, yang berarti terdapat pengaruh yang positif dan signifikan antara pendidikan terhadap prestasi kerja di Rumah Sakit Umum Daerah Aek Kanopan Kabupaten Labuhanbatu Utara.

\section{b. Pengaruh pelatihan $\left(X_{2}\right)$ Terhadap prestasi kerja pegawai (Y)}

Berdasarkan hasil penelitian secara parsial (Uji-t) Terdapat pengaruh yang positif dan signifikan antara pelatihan terhadap prestasi kerja di Rumah Sakit Umum Daerah Aek Kanopan Kabupaten Labuhanbatu Utara.. Berdasarkan hipotesis kedua ini dilakukan pengujian dengan menggunakan uji t. Hasil perhitungan secara parsial ini menunjukkan bahwa pelatihan memiliki nilai $t_{\text {hitung }}$ sebesar 6,595 dan nilai $\mathrm{t}_{\text {tabel }}$ sebesar $1,668\left(\mathrm{t}_{\text {hitung }}\right.$ $\left.>t_{\text {tabel }}: 6,977>1,668\right)$ serta taraf signifikasi $0,00<0.05$, dengan demikian dapat disimpulkan bahwa $\mathrm{H}_{\mathrm{a}}$ diterima dan $\mathrm{H}_{0}$ ditolak, yang berarti terdapat pengaruh yang positif dan signifikan antara pelatihan terhadap. prestasi kerja di Rumah Sakit Umum Daerah Aek Kanopan Kabupaten Labuhanbatu Utara.
c. Pengaruh pendidikan $\left(\mathbf{X}_{1}\right)$ dan pelatihan $\left(\mathbf{X}_{2}\right)$, Terhadap prestasi kerja karyawan (Y)


Berdasarlan hasil uji simultan (UjiF) Terdapat pengaruh yang positif dan signifikan antara pendidikan dan pelatihan secara simultan terhadap prestasi kerja di Rumah Sakit Umum Daerah Aek Kanopan Kabupaten Labuhanbatu Utara.". Berdasarkan hipotesis pertama ini dilakukan pengujian dengan menggunakan uji F. Hasil perhitungan secara simultan ini menunjukkan bahwa pendidikan dan pelatihan memiliki nilai $F_{\text {hitung }}$ sebesar 31,332 dan nilai $F_{\text {tabel }}$ sebesar 3,11 ( $t_{\text {hitung }}$ $\left.>t_{\text {tabel }}: 31,332>3,11\right)$ serta taraf signifikasi $0,00<0.05$, dengan demikian dapat disimpulkan bahwa $\mathrm{H}_{\mathrm{a}}$ diterima dan $\mathrm{H}_{0}$ ditolak, yang berarti terdapat pengaruh yang positif dan signifikan antara pendidikan dan pelatihan secara simultan terhadap prestasi kerja di Rumah Sakit Umum Daerah Aek Kanopan Kabupaten Labuhanbatu Utara.

\section{KESIMPULAN}

Hasil penelitian dan pembahasan tentang pengaruh pendidikan dan pelatihan terhadap prestasi kerja di Rumah Sakit Umum Daerah Aek Kanopan Kabupaten Labuhanbatu Utara, maka penulis mengambil kesimpulan :

1. Secara parsial variabel pendidikan memiliki pengaruh positif dan signifikan terhadap prestasi kerja . Hal ini terlihat dari nilai $t$ hitung $>$ $t_{\text {tabel }}(6,595>1,668)$ dengan nilai signifikan $0,00<0.05 \quad$ Sehingga keputusan yang diambil adalah ha diterima dan ho ditolak.

2. Secara parsial variabel pelatihan memiliki pengaruh positif dan signifikan terhadap prestasi kerja . Hal ini terlihat dari nilai $t$ hitung $>$ $t_{\text {tabel }}(6,977>1,668)$ dengan nilai signifikan $\quad 0,00<0,05$. Sehingga keputusan yang diambil adalah ha diterima dan ho ditolak.

3. Secara simultan variabel pendidikan dan pelatihan memiliki pengaruh positif dan signifikan terhadap prestasi kerja. Hal ini terlihat dari nilai $\mathrm{F}$ hitung $>\mathrm{F}$ tabel $(31,332>3,11)$ dan nilai signifikan $0,00<0,05$.

\section{SARAN}

Berdasarkan hasil analisis dan kesimpulan penelitian, maka dianjurkan beberapa saran sebagai berikut :

1. Sebaiknya pimpinan lebih memperhatikan pendidikan para karyawan agar peningkatan sikap seseorang dalam melaksanakan tugasnya dalam rangka pencapaian tujuan organisasi.

2. Dianjurkan pada peneliti selanjutnya untuk menambahkan variabel yang lebih komplek dalam penelitian.

3. Sebaiknya pimpinan agar lebih memperhatikan program pendidikan dan pelatihan para pegawai karena bagi pegawai sangatlah penting untuk masa sekarang maupun yang akan datang , karena dengan adanya pendidikan dan pelatihan akan lebih meningkatkan prestasi kerja karyawan.yang ada di Rumah Sakit Uum Daerah Aek Kanopan Kabupaten Labuhanbatu Utara.

\section{DAFTAR PUSTAKA}

Handoko.T.Hani. 2007, Manajemen Personalia dan Sumber Daya manusia, Penerbit BPFE Universitas Gajah Mada Yogyakarta. 
Hasibuan, Malayu. SP, 2008. Manajemen Sumber Daya Manusia, Jakarta, Bumi Aksara.

Mangkunegara. A.Prabu, 2000, Manajemen Sumber Daya manusia, Penerbit : PT.Remaja Rosdakarya, Bandung.

Moekijat, Evaluasi Pelatihan Dalam Rangka Meningkatkan Produktivitas Perusahaan, Bandung, Penerbit: Mandar Maju 1990.
Rivai Veithzal 2004, Manajemen Sumber Daya Manusia Untuk Perusahaan, Jakarta. Penerbit : PT. Raja Grafindo Penada.

Soekidjo Notoatmodjo, 2003, Pendidikan dan Perilaku Kesehatan. Jakarta: PT. Rineka Cipta.

Sugiyono (2011), Statistik Untuk Penelitian, Bandung, Alfabeta 